\title{
Rancang Bangun Aplikasi Simulasi Dekorasi Ruangan dengan Memanfaatkan Teknologi Markerless Augmented Reality
}

\author{
(Design of Room Decoration Simulation Application by utilizing Markerless \\ Augmented Reality Technology)
}

\author{
Putu Anggara Mahardika*, I Made Arsa Suyadnya, Komang Oka Saputra \\ Program Studi Teknik Elektro, Fakultas Teknik, Universitas Udayana \\ Jl. Kampus Bukit Jimbaran, Bali, INDONESIA \\ Email: mahardikanggara@gmail.com, arsa.suyadnya@unud.ac.id, okasaputra@unud.ac.id
}

*Penulis korespondensi

\begin{abstract}
Markerless Augmented Reality (AR) is a technology that combines two-dimensional or threedimensional virtual objects into a real environment and then projects these virtual objects in real time without the need for a special marker. In this research, the Markerless AR application will be used to simulate room decoration with 3-dimensional objects. This research was built using the Java programming language and using supporting applications namely Android Studio and Wikitude library. Based on the results of testing with the Black-box method, the overall functionality of the application has run well, besides testing also uses the System Usability Scale (SUS) method by giving questionnaires to 20 application users. The results of the System Usability Scale (SUS) test obtained an average score of 73.13. In grouping the SUS percentile score, the value of 73.13 is in Class $C$, wherein this assessment the application is acceptable and can be used easily by the user.
\end{abstract}

Key words: markerless augmented reality, room decoration, java, android, wikitude library

\section{Pendahuluan}

Pada era saat ini, kebutuhan akan desain interior ruangan sudah menjadi hal yang tidak mengherankan lagi. Kemampuan ekonomi masyarakat saat ini membuat keinginan untuk mendesain interior ruangan sesuai dengan yang diharapkan menjadi hal yang tidak mustahil. Ruangan akan terasa lebih nyaman dan lebih berfungsi bila ditata dengan baik sesuai dengan tata letak suatu ruangan. Maka dari itu mendesain interior ruangan menjadi sebuah pekerjaan yang sangat menguntungkan bagi mereka yang mampu mewujudkan desain interior ruangan sesuai yang diharapkan oleh konsumen.

Saat ini, konsumen ingin melihat secara real time desain interior yang akan dibuat sedangkan untuk desainer mengalami kesulitan dalam memenuhi keinginan konsumen, dikarenakan biaya untuk membuat suatu desain tidaklah murah. Disisi lain untuk menampilkan desain secara real time, produsen harus mendatangkan furniture langsung ke dalam ruangan konsumen. Selain itu posisi furniture yang diinginkan juga bisa berubahubah sesuai dengan keinginan konsumen dan itu memakan waktu dan tenaga yang dapat menyebabkan pembengkakan biaya untuk mendesain sebuah ruangan.

Dengan menggunakan teknologi augmented reality pengguna dapat mendekorasi atau mendesain suatu ruangan tanpa harus mendatangkan furniture tersebut ke dalam ruangan. Augmented reality (AR) merupakan teknologi yang menggabungkan dua aspek yaitu benda maya dua dimensi dan tiga dimensi ke dalam suatu realitas atau lingkungan nyata [1]. Dengan memproyeksikan benda maya ke dalam realitas dapat membantu manusia untuk mendapatkan suatu informasi dan membantu interaksi penggunaannya. Informasi yang ditampilkan benda maya dapat membantu manusia melakukan kegiatan dalam dunia nyata. Alternatif pemanfaatan AR dapat dilakukan dengan dua metode yakni marker based tracking dan markerless augmented reality. Pada metode marker based tracking pelacakan didasarkan pada objek marker yang telah ditentukan, sedangkan pada markerless AR tidak memerlukan marker khusus melainkan menggunakan teknik pengenalan pola objek dunia nyata maupun titik-titik fitur alami [2]. Pemanfaatan AR pun dapat dikembangkan pada aplikasi berbasis mobile dengan memanfaatakan AR Software Development Kit (SDK) yang tersedia. Penelitian ini akan membahas mengenai pengembangan sebuah aplikasi mobile untuk simulasi dekorasi ruangan dengan memanfaatkan Markerless AR.

\section{TinjauAn Pustaka DAN DASAR TeORI}

\section{A. Tinjauan Pustaka}

Penelitian mengenai pemanfaatan augmented reality untuk mensimulasikan dekorasi interior ruangan sudah beberapa kali dilakukan sebelumnya. Penelitian sebelumnya memanfaatkan AR untuk menampilkan katalog furniture berdasarkan objek marker. Pada penelitian ini, aplikasi dapat memvisualisasikan atau 
menampilkan sebuah objek tiga dimensi (3D) dari beberapa kategori furniture yaitu sofa, kursi dan rak buku menggunakan media mobile smartphone Android berdasarkan objek marker. Objek marker tersebut diambil dari gambar katalog produk dan dikemas ke dalam sebuah aplikasi Android [3]. Penelitian berikutnya juga mengembangkan aplikasi Android yang dapat mensimulasikan dekorasi ruangan secara real time dengan menggunakan objek marker. Aplikasi ini dibangun memanfaatkan Vuforia SDK untuk pembuatan marker-nya. Dengan aplikasi ini, pengguna tidak perlu lagi mendatangkan suatu furniture ke dalam ruangan untuk mendekorasi suatu ruangan. Pengguna dapat menentukan letak objek 3D dengan memindahkan marker-marker yang tersedia dan melihatnya langsung dari layar perangkat mobile Android [4]. Selain menggunakan objek marker, penelitian lainnya membangun markerless AR untuk melakukan simulasi dekorasi interior ruangan. Pengembangan markerless AR ini memanfaatkan Metaio SDK [5], namun sejak tahun 2015 SDK ini sudah tidak dapat digunakan secara bebas. Penelitian dengan memanfaatkan markerless $A R$ juga dilakukan untuk membangun aplikasi AR Furniture. Aplikasi ini dibangun dengan menggunakan Kudan SDK yang telah mendukung teknologi SLAM (Simultaneous Localization and Mapping) [6] .

Berdasarkan penelitian-penelitian sebelumnya, sebagian masih menggunakan objek marker sebagai penanda untuk menampilkan suatu objek dan ada juga yang telah menerapkan markerless AR untuk menampilkan objek maya. Pada penelitian ini akan menerapkan teknologi markerless AR dimana markerless sendiri tidak membutuhkan suatu penanda khusus untuk menampilkan objek 3D. Aplikasi ini dibangun menggunakan software Android Studio dan library Wikitude. Wikitude SDK juga telah mendukung instant tracking dengan teknologi SLAM. Adanya aplikasi ini, diharapkan dapat memudahkan pengguna dalam mendesain interior ruangan, seperti memilih furniture yang diinginkan dan menyesuaikan penempatannya dalam ruangan.

\section{B. Dasar Teori}

\section{B.1. Markerless Augmented Reality}

Markerless adalah suatu metode pada augmented reality yang digunakan untuk melacak suatu objek pada dunia nyata tanpa perlu menggunakan suatu marker khusus atau marker spesial. Metode Markerless ini didukung oleh teknik pattern recognition yaitu suatu teknik yang digunakan untuk mengenal suatu pola objek dunia nyata, jadi penggunaan marker sebagai object tracking digantikan oleh permukaan suatu objek. Tracking object pada markerless dilakukan dengan menghitung posisi antara kamera dan dunia nyata dengan hanya menggunakan titik - titik fitur alami [2]. Pada metode Markeless AR ini terdapat beberapa macam Teknik markerless tracking seperti Face Tracking, 3D object, dan Motion Tracking [7] .

\section{B.1.1 Face Tracking}

Teknik face tracking menggunakan suatu algoritma khusus dimana dengan algoritma ini kamera dapat mengenali wajah manusia dengan cara mengenali posisi hidung, mata, dan mulut manusia, kemudian kamera mengabaikan objek - objek yang ada di sekitarnya seperti lemari, kursi, pohon dan benda lain. Ilustrasi face tracking dapat dilihat pada Gambar 1.

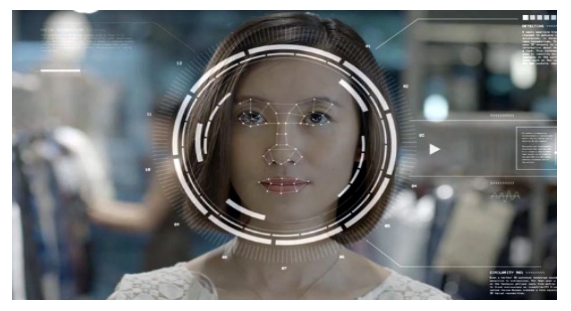

Gambar 1. Face Tracking

\section{B.1.2. 3D Object Tracking}

Teknik 3D object tracking merupakan suatu teknik pada markerless augmented reality yang dapat mengenali semua bentuk objek yang ada pada dunia nyata seperti meja, mobil, lemari, dan lainnya. Ilustrasi mengenai teknik 3D object tracking dapat dilihat pada Gambar 2.

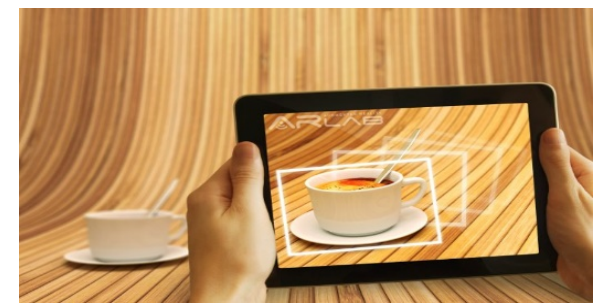

Gambar 2. 3D Object Tracking

\section{B.1.3. Motion Tracking}

Pada teknik motion tracking, kamera dapat menangkap gerakan yang terdapat pada dunia nyata. Motion tracking digunakan pada produksi pembuatan film-film yang mensimulasikan beberapa gerakan. Ilustrasi teknik motion tracking dapat dilihat pada Gambar 3.

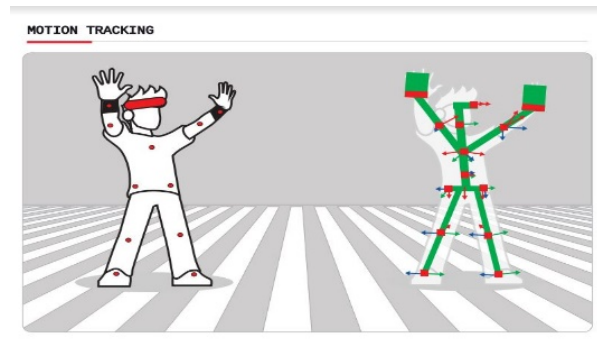

Gambar 3. Motion Tracking

\section{B.1.4. GPS Based Tracking}

Teknik GPS based tracking memanfaatkan fitur GPS dan kompas yang ada pada smartphone. Dengan memanfaatkan fitur tersebut, aplikasi AR yang dibangun dapat mengambil data dari GPS dan kompas yang 
kemudian ditampilkan dalam bentuk arah secara realtime. Visualisasinya pun dapat dalam 3 dimensi (3D).

\section{B.2. Wikitude}

Wikitude merupakan software library untuk augmented reality. Awalnya software library ini berfokus pada augmented reality berbasis lokasi dengan produk Wikitude World Browser App. Pada tahun 2008 Wikitude pertama kali mengeluarkan Software Development Kit (SDK) dengan menyertakan pengenalan gambar, rendering model 3D, AR berbasis lokasi dan teknologi SLAM (Simultaneous Localization and Mapping) yang memungkinkan pengenalan objek dan pelacakan objek tanpa memerlukan penanda. Pelacakan dengan teknologi SLAM berbasis pada pembuatan 3D map dari suatu lingkungan dan menggunakannya sebagai referensi pelacakan. Dengan dukungan Android Studio dan Unity 3D, platform Wikitude SDK dapat berjalan pada sistem operasi Android dan iOS [8].

\section{B.3. Android}

Android adalah suatu sistem operasi perangkat mobile. Android merupakan sistem operasi yang berisikan middleware dan aplikasi-aplikasi pendukung dasar. Pada pengembangan aplikasi Android menggunakan bahasa pemrograman Java, dimana konsep-konsep pada pemrograman Java berhubungan dengan pemrograman yang berbasis objek. Disamping itu dalam pengembangan suatu aplikasi Android membutuhkan SDK yaitu Software Development Kit yang berfungsi sebagai pembuka jalan bagi programmer untuk mengakses Application Programming Interface (API) pada Android [9].

\section{B.4. Black Box Testing}

Black-Box testing merupakan pengujian fungsional perangkat lunak yang berbasis hasil output dari suatu input yang diberikan ke perangkat lunak. Pengujian ini tidak memerlukan pengetahuan mengenai struktur internal atau coding dari perangkat lunak. Pengujian ini dilakukan untuk memeriksa aspek fundamental dari perangkat lunak atau sistem, dimana memastikan bahwa input diterima dengan benar dan menghasilkan output yang sesuai [10].

\section{B.5. System Usability Scale (SUS)}

System Usability Scale adalah uji persepsi kegunaan sistem dengan cara memberikan kuisioner kepada pengguna sistem. Pada kuisioner ini terdapat 10 pertanyaan yang diikuti dengan 5 opsi jawaban pada setiap pertanyaannya, mulai dari sangat tidak setuju hingga sangat setuju [11]. Kuesioner SUS sedikitnya melibatkan sebanyak 20 orang pengguna sistem.

Setiap pertanyaan pada metode SUS memiliki bobot antara 0 sampai 4 . Dalam perhitungan nilai SUS, nilai dari pertanyaan nomor $1,3,5,7,9$ akan dikurangi 1 dan nilai dari pertanyaan nomor 2,4,6,8,10 dikurangi dengan 5. Selanjutnya setiap hasil tersebut dikalikan dengan 2,5 dan dihitung rata-ratanya untuk memperoleh nilai akhir. Nilai akhir SUS berada di atas rata-rata jika bernilai lebih dari 68 [11]. Nilai akhir SUS dapat ditafsirkan dalam perbandingan range nilai seperti Gambar 5 [12]. Sebagai contoh, apabila nilai rata-rata akhir SUS adalah 72 maka berdasarkan Gambar 4, nilai tersebut berada pada acceptability ranges: acceptable, adjective ratings: good dan grade scale: $\mathrm{C}$.

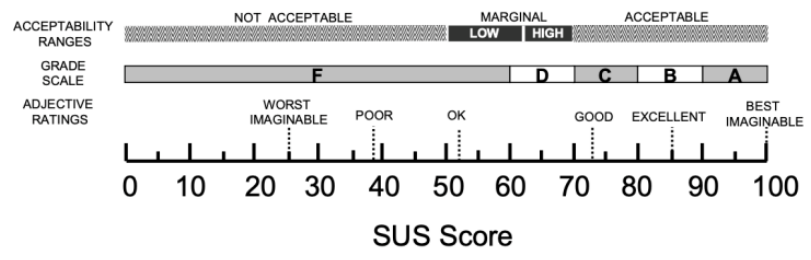

Gambar 4. Perbandingan range nilai rata-rata SUS

\section{Metodologi Penelitian}

\section{A. Tahapan Penelitian}

Dalam penulisan penelitian ini, terdapat beberapa tahapan yang dilakukan yang dapat dilihat pada Gambar 5.

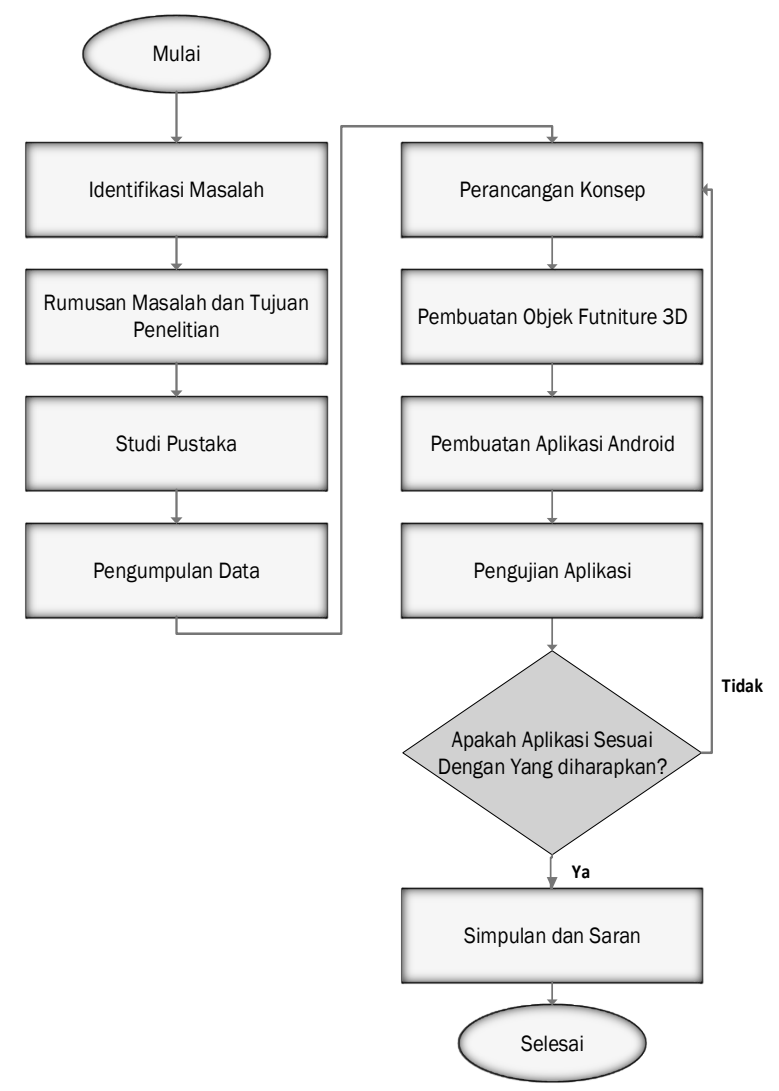

Gambar 5. Flowchart tahapan penelitian

Adapun penjelasan dari tahapan penelitian yang digambarkan pada gambar 5 adalah sebagai berikut.

1. Identifikasi Masalah

Merupakan langkah pertama yang dilakukan dalam suatu penelitian. Dalam tahap ini langkah yang 
dilakukan adalah mengidentifikasikan masalah untuk menghindari kerancuan serta menentukan studi kasus yang nanti akan digunakan.

2. Rumusan Masalah dan Tujuan Penelitian

Setelah identifikasi masalah, selanjutnya merumuskan suatu masalah secara rinci agar mengetahui pokok dari suatu permasalahan.

3. Studi Pustaka

Setelah rumusan masalah, selanjutnya adalah tahapan studi pustaka. Studi pustaka dilakukan untuk lebih memahami teori-teori yang berhubungan dengan pemecahan masalah.

4. Pengumpulan Data

Tujuan dari pengumpulan data adalah untuk memperoleh bahan penelitian sesuai dengan tujuan penelitian yang telah ditetapkan.

5. Perancangan Konsep

Perancangan aplikasi ini dibuat dalam bentuk use case diagram, activity diagram, structure chart dan flowchart.

6. Pembuatan Objek Furniture 3D

Proses pembuatan objek furniture 3D dengan menggunakan aplikasi clara.io.

7. Pembuatan Aplikasi Android

Proses pembuatan aplikasi Android merupakan proses pembangunan aplikasi mobile untuk mensimulasikan dekorasi ruangan sederhana dengan teknologi markerless augmented reality. Aplikasi dibangun menggunakan software Android Studio dan library Wikitude versi 8.0.0.

8. Pengujian Sistem

Metode pengujian sistem yang akan digunakan untuk menguji aplikasi ini menggunakan metode pengujian Black Box dan System Usability Scale.

9. Simpulan dan Saran

Tahap simpulan dan saran dilakukan agar dapat menyimpulkan hasil penelitian secara singkat dan jelas, serta dapat memberikan saran untuk pengembangan sistem berikutnya.

\section{B. Gambaran Umum Sistem}

Gambaran umum sistem menjelaskan tentang aplikasi yang akan dibangun dan proses yang terjadi antara sistem atau perangkat lunak dengan pengguna. Langkah pertama pengguna memulai aplikasi, pengguna akan melihat splash screen dan pengguna langsung diarahkan pada tampilan kamera. Selanjutnya pengguna menentukan target marker dan memilih objek furniture yang diinginkan. Terdapat menu screenshot dimana menu tersebut digunakan untuk menyimpan hasil dari dekorasi ruangan, dan menu putar yaitu untuk memutar objek serta menu hapus untuk menghapus objek. Gambaran umum sistem Markerless Augmented Reality ini dapat dilihat pada Gambar 6.

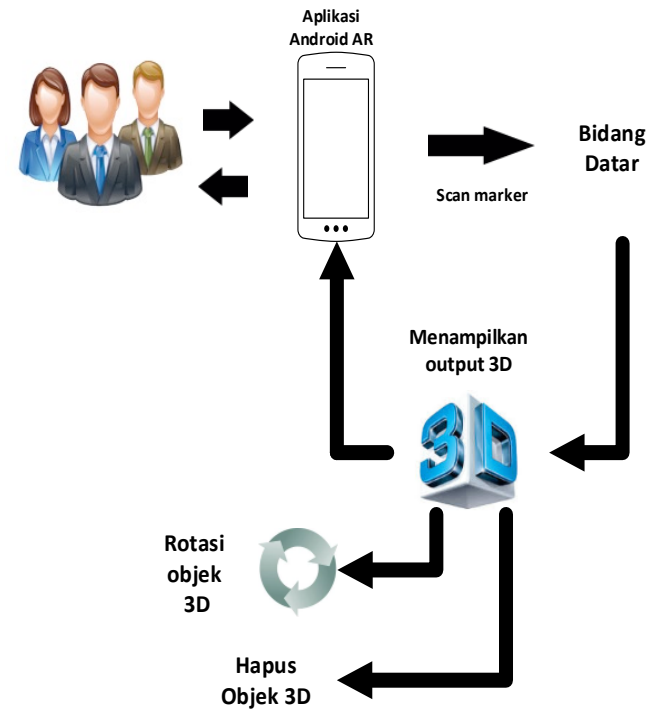

Gambar 6. Gambaran umum aplikasi

\section{Use Case Diagram}

Use Case diagram adalah gambaran fungsional dari suatu sistem, diharapkan dengan Use Case Diagram pengguna sistem lebih memahami dan mengerti tentang kegunaan dan manfaat dari sistem yang akan dibangun. Use Case Diagram dapat dilihat pada Gambar 7.

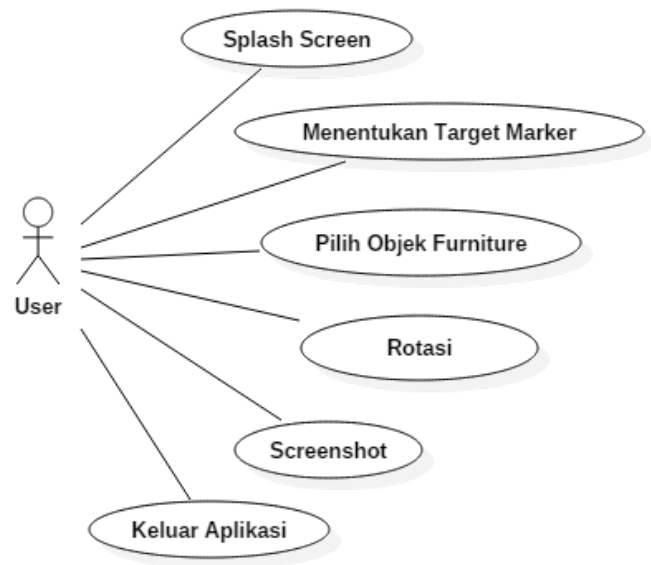

Gambar 7. Use case diagram.

Gambar 7 menampilkan semua fitur aplikasi yang dilihat dan diakses oleh pengguna, diantaranya saat pengguna memulai aplikasi akan ditampilkan splash screen yang berisikan logo library Wikitude sebagai tampilan awal sebelum aplikasi dapat digunakan. Setelah splash screen, aplikasi akan siap digunakan. Pengguna menentukan target marker dan selanjutnya pengguna akan melihat beberapa objek furniture yang dapat dipilih untuk dimunculkan dalam bentuk tiga dimensi (3D).

\section{Structure Chart Aplikasi}

Structure chart berfungsi mengilustrasikan organisasi dari aplikasi yang menggambarkan bagian-bagian modul. Rancangan structure chart sebagai struktur dasar 
perancangan aplikasi markerless augmented reality dapat dilihat pada Gambar 8.

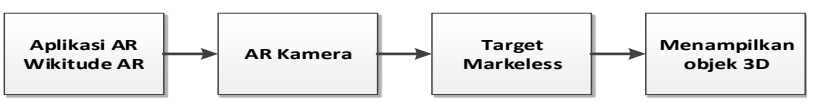

Gambar 8. Structure chart

Aplikasi markerless augmented reality, menggunakan Wikitude AR sebagai tempat untuk penyimpanan dan pengolahan objek tiga dimensi (3D) dan sebagai pelacak pada kamera. Aplikasi memanfaatkan kamera dari smartphone yang digunakan untuk mendeteksi target, kemudian menampilkan objek tiga dimensi (3D).

\section{E. Activity Diagram Markerless Augmented Reality}

Activity diagram merupakan proses yang berjalan pada saat pengguna akan menggunakan aplikasi. Setelah pengguna melihat tampilan splash screen, maka aplikasi akan menampilkan kamera utama AR. Pengguna mengarahkan smartphone Android ke arah target dan kamera akan melakukan proses scan. Jika area scan markerless sesuai, maka akan tampil objek furniture tiga dimensi (3D). Jika area scan markerless gagal atau tidak sesuai, maka akan dilakukan scan ulang. Setelah muncul objek 3D, maka pengguna dapat merotasi objek 3D dan dapat melakukan fungsi screenshot untuk menyimpan hasil dekorasi yang telah dilakukan. Activity Diagram dapat dilihat pada Gambar 9.

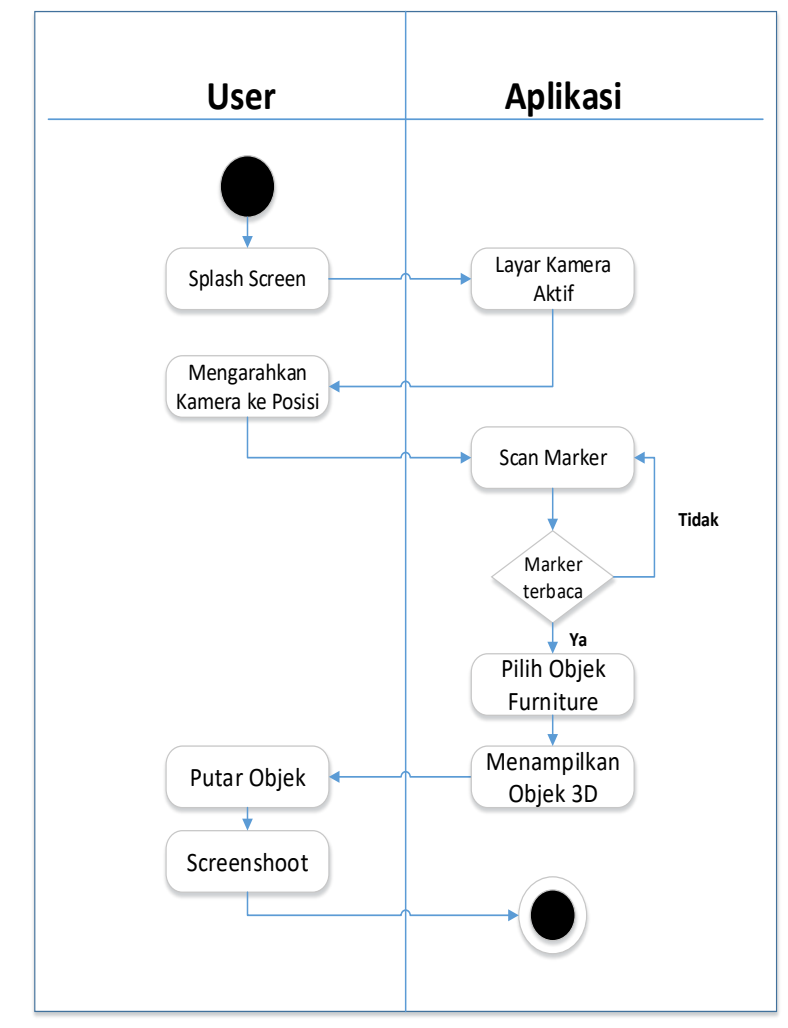

Gambar 9. Activity diagram aplikasi markerless augmented reality

\section{F. Rancangan Antarmuka}

Dalam perancangan aplikasi Augmented Reality simulasi dekorasi ruangan dengan memanfaatkan teknologi markerless AR terdiri dari dua bagian rancangan antarmuka yaitu: desain antarmuka splash screen aplikasi markerless AR dan desain antarmuka menu utama aplikasi markeless AR.

\section{Desain Antarmuka Splash Screen}

Tampilan awal berupa splash screen akan ditampilkan pada layar ketika aplikasi baru dijalankan. Pada layout splash screen akan menampilkan logo Wikitude, lambang Udayana dan nama pembuat aplikasi. Desain splash screen dapat dilihat pada Gambar 10.

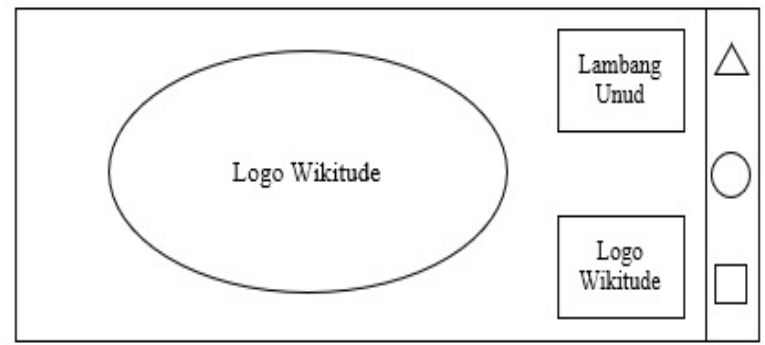

Gambar 10. Desain splash screen

\section{Desain antarmuka Menu Utama}

Tampilan menu utama akan muncul setelah splash screen dan merupakan tampilan kamera pada perangkat smartphone Android. Dalam antarmuka menu utama ditampilan tombol-tombol fitur yang direncanakan. Desain menu utama dapat dilihat pada Gambar 11.

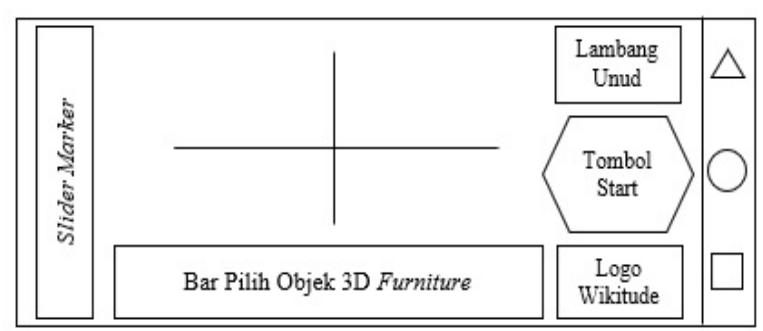

Gambar 11. Desain menu utama

\section{HASIL DAN PEMBAHASAN}

\section{A. Hasil}

Rancangan aplikasi markerless augmented reality ini direalisasikan dengan menggunakan bahasa pemrograman Java pada Android Studio dan library Wikitude SDK versi 8.0.0. Aplikasi ini dibangun dengan menggunakan Android SDK 4.4 (KitKat) / API level 19 sehingga minimal dapat berjalan pada smartphone dengan OS Android Kitkat (4.4) atau yang lebih baru. Aplikasi ini berjalan pada platform mobile Android yang dapat digunakan sebagai media untuk simulasi dekorasi suatu ruangan. Dengan hadirnya aplikasi ini dan dengan penerapan teknologi augmented reality objek data ditampilkan seolah-olah seperti aslinya. 


\section{B. Pembahasan Keseluruhan Sistem}

Aplikasi simulasi dekorasi ruangan dengan memanfaatkan teknologi markeless augmented reality adalah aplikasi yang digunakan sebagai media dalam menata ruangan yang diinginkan. Adapun hasil perancangan membahas mengenai desain aplikasi, serta hasil akhir perancangan aplikasi sebagai berikut.

\section{Slider Marker}

Pertama untuk menjalankan Aplikasi markerless augmented reality pengguna mengatur luas marker yang akan digunakan dengan menggeser ke atas dan ke bawah pada slider marker. Slider Marker dapat dilihat pada Gambar 12.

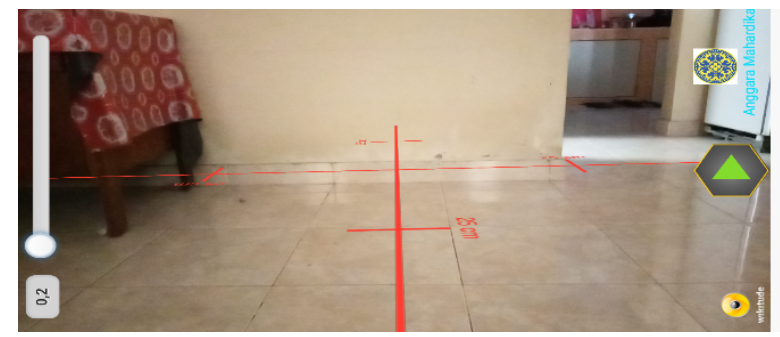

Gambar 12. Tampilan slider marker

\section{Tombol Scan Marker}

Tombol Scan Marker ini digunakan untuk menjalankan aplikasi markerless augmented reality. Setelah pengguna selesai mengatur area marker selanjutkan tekan tombol scan untuk mengunci area marker yang akan digunakan. Setelah menekan tombol scan, penanda marker akan otomatis berubah warna menjadi warna biru. Tombol Scan Marker dapat dilihat pada Gambar 13.

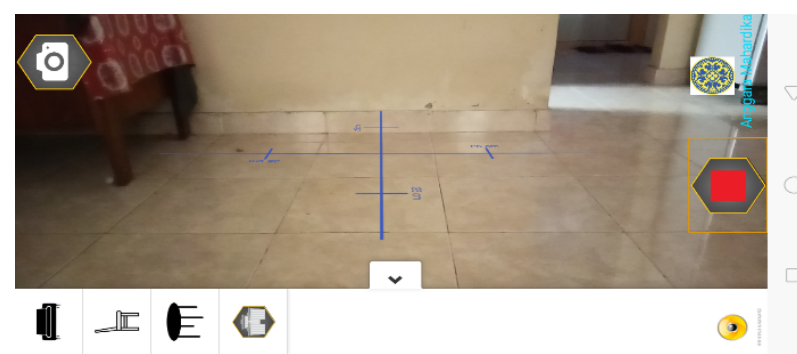

Gambar 13. Tombol scan marker

3. Tombol Pilih Objek

Tombol pilih objek otomatis akan muncul pada saat pengguna menekan tombol scan marker. Pengguna dapat memilih objek yang sudah disediakan dengan men-drag objek yang dipilih ke dalam area marker. Tombol Pilih Objek dapat dilihat pada Gambar 14.

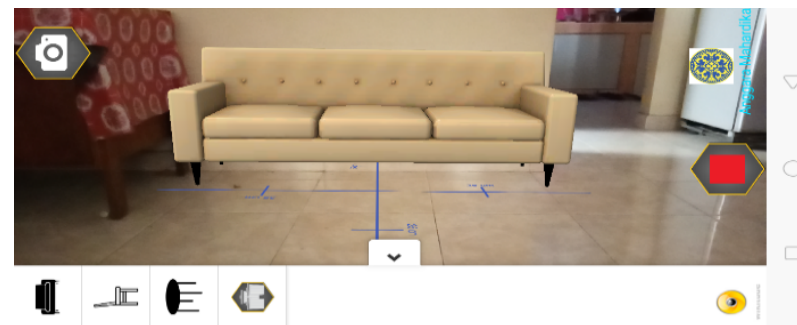

Gambar 14. Tombol pilih objek

4. Tombol Hapus Objek

Tombol hapus objek berfungsi untuk menghapus semua objek yang telah digunakan untuk mensimulasikan dekorasi suatu ruangan. Tombol Hapus Objek dilihat pada Gambar 15.

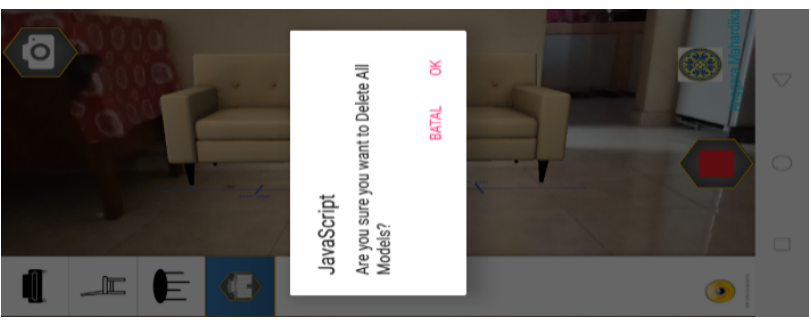

Gambar 15. Tombol Hapus Objek

\section{Tombol Screenshot}

Tombol Screenshot berfungsi untuk menyimpan hasil dari dekorasi yang dilakukan oleh pengguna berupa foto dengan format .jpg yang tersimpan dalam folder yang sudah disediakan dari aplikasi markerless AR. Tombol Screenshot dapat dilihat pada Gambar 16.

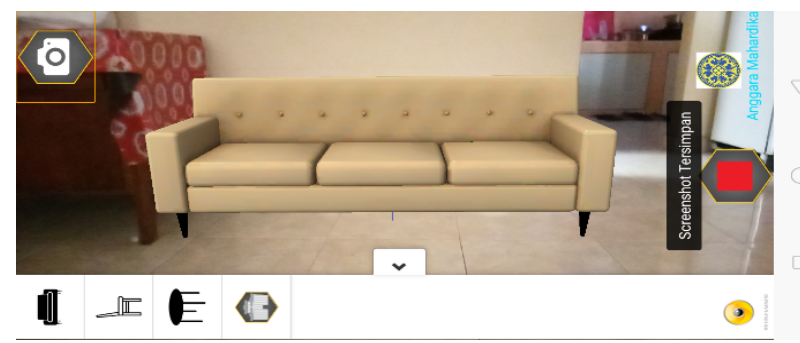

Gambar 16. Tombol screenshot

\section{Pengujian Black-Box}

Pengujian black-box pada penelitian ini berfokus pada fungsi tombol yang ada pada aplikasi. Pada setiap tombol akan diuji hasil output-nya dan secara keseluruhan tidak terdapat error yang diperoleh dari pengujian tersebut. Pada Tabel I menggambarkan hasil dari pengujian aplikasi menggunakan metode black-box. 
TABEL I. Hasil Pengujian Black-BoX

\begin{tabular}{|c|l|l|l|l|l|l|}
\hline No & $\begin{array}{l}\text { Nama } \\
\text { Pengujian }\end{array}$ & $\begin{array}{l}\text { Bagian } \\
\text { yang } \\
\text { Diuji }\end{array}$ & $\begin{array}{l}\text { Tindakan } \\
\text { Pengujian }\end{array}$ & $\begin{array}{l}\text { Jenis } \\
\text { Penguji- } \\
\text { an }\end{array}$ & $\begin{array}{l}\text { Teknik } \\
\text { Penguji- } \\
\text { an }\end{array}$ & Hasil Uji \\
\hline 1 & $\begin{array}{l}\text { Tombol } \\
\text { Scan } \\
\text { marker }\end{array}$ & $\begin{array}{l}\text { Tombol } \\
\text { Scan } \\
\text { marker }\end{array}$ & $\begin{array}{l}\text { Klik } \\
\text { Tombol } \\
\text { Scan }\end{array}$ & Sistem & $\begin{array}{l}\text { Black- } \\
\text { Box }\end{array}$ & Berhasil \\
\hline 2 & $\begin{array}{l}\text { Tombol } \\
\text { Pilih } \\
\text { Objek }\end{array}$ & $\begin{array}{l}\text { Tombol } \\
\text { Pilih } \\
\text { Objek }\end{array}$ & $\begin{array}{l}\text { Klik Pilih } \\
\text { Objek }\end{array}$ & Sistem & $\begin{array}{l}\text { Black- } \\
\text { Box }\end{array}$ & Berhasil \\
\hline 3 & $\begin{array}{l}\text { Tombol } \\
\text { Hapus } \\
\text { Objek }\end{array}$ & $\begin{array}{l}\text { Tombol } \\
\text { Hapus } \\
\text { Objek }\end{array}$ & $\begin{array}{l}\text { Klik } \\
\text { Hapus } \\
\text { Objek }\end{array}$ & Sistem & $\begin{array}{l}\text { Black- } \\
\text { Box }\end{array}$ & Berhasil \\
\hline 4 & $\begin{array}{l}\text { Slider } \\
\text { Marker }\end{array}$ & $\begin{array}{l}\text { Slider } \\
\text { Marker }\end{array}$ & $\begin{array}{l}\text { Menggeser } \\
\text { slider } \\
\text { marker }\end{array}$ & Sistem & $\begin{array}{l}\text { Black- } \\
\text { Box }\end{array}$ & Berhasil \\
\hline 5 & $\begin{array}{l}\text { Tombol } \\
\text { Screenshot }\end{array}$ & $\begin{array}{l}\text { Tombol } \\
\text { Screen } \\
\text { shot }\end{array}$ & $\begin{array}{l}\text { Klik } \\
\text { Tombol } \\
\text { Screenshot }\end{array}$ & Sistem & $\begin{array}{l}\text { Black- } \\
\text { Box }\end{array}$ & Berhasil \\
\hline
\end{tabular}

Dari hasil pengujian pada Tabel I dapat dilihat bahwa semua kebutuhan yang diuji dinyatakan berhasil.

\section{Pengujian Usability}

Pengujian ini dilakukan dengan memberikan responden sebuah smartphone dengan aplikasi simulasi dekorasi ruangan yang ter-install di dalamnya, selanjutnya responden akan melengkapi isian kuisioner dan terakhir melakukan analisis dari hasil usability testing untuk rekomendasi perbaikan sistem ke depannya. Tabel II merupakan data hasil survei menggunakan metode System Usability Scale.

TABEL II. DATA HASIL SURVEI SySTEM USABILITy SCALE

\begin{tabular}{|c|l|l|l|l|l|l|l|l|l|l|}
\hline \multirow{2}{*}{ Responden n } & \multicolumn{10}{|c|}{ Pertanyaan } \\
\cline { 2 - 10 } & $\mathbf{1}$ & $\mathbf{2}$ & $\mathbf{3}$ & $\mathbf{4}$ & $\mathbf{5}$ & $\mathbf{6}$ & $\mathbf{7}$ & $\mathbf{8}$ & $\mathbf{9}$ & $\mathbf{1 0}$ \\
\hline 1 & 3 & 2 & 4 & 3 & 3 & 2 & 4 & 1 & 3 & 3 \\
\hline 2 & 4 & 1 & 3 & 1 & 4 & 1 & 4 & 3 & 3 & 3 \\
\hline 3 & 3 & 0 & 4 & 1 & 4 & 0 & 4 & 1 & 4 & 1 \\
\hline 4 & 3 & 2 & 4 & 1 & 3 & 1 & 4 & 0 & 2 & 1 \\
\hline 5 & 3 & 2 & 3 & 1 & 4 & 0 & 3 & 2 & 3 & 1 \\
\hline 6 & 1 & 0 & 4 & 3 & 4 & 0 & 4 & 4 & 3 & 1 \\
\hline 7 & 3 & 0 & 3 & 3 & 4 & 1 & 3 & 0 & 3 & 0 \\
\hline 8 & 2 & 1 & 4 & 3 & 3 & 1 & 3 & 0 & 4 & 1 \\
\hline 9 & 3 & 3 & 4 & 1 & 4 & 0 & 2 & 1 & 3 & 1 \\
\hline 10 & 2 & 3 & 4 & 2 & 4 & 1 & 4 & 0 & 3 & 1 \\
\hline 11 & 1 & 2 & 3 & 2 & 3 & 1 & 3 & 2 & 1 & 4 \\
\hline 12 & 3 & 1 & 4 & 1 & 3 & 1 & 3 & 3 & 3 & 3 \\
\hline 13 & 1 & 1 & 4 & 1 & 3 & 2 & 4 & 3 & 3 & 1 \\
\hline 14 & 3 & 2 & 4 & 3 & 3 & 1 & 3 & 0 & 2 & 1 \\
\hline 15 & 3 & 1 & 3 & 1 & 2 & 1 & 3 & 1 & 3 & 1 \\
\hline 16 & 3 & 0 & 4 & 1 & 3 & 0 & 4 & 1 & 4 & 0 \\
\hline 17 & 3 & 0 & 3 & 3 & 4 & 1 & 3 & 1 & 4 & 0 \\
\hline 18 & 3 & 1 & 3 & 0 & 4 & 0 & 3 & 1 & 3 & 1 \\
\hline 19 & 4 & 1 & 3 & 1 & 3 & 1 & 4 & 3 & 3 & 0 \\
\hline 20 & 1 & 1 & 4 & 1 & 3 & 2 & 4 & 4 & 1 & 3 \\
\hline
\end{tabular}

Tahapan selanjutnya adalah mengkonversikan skala nilai dari pernyataan tiap responden sesuai aturan System
Usability Scale. Hasil dari pengujian dengan System Usabilty Scale (SUS) yang sudah dikonversikan dapat dilihat pada Tabel III.

TABEL III. DATA HASIL SURVEI SyStem USABILITY SCALE (SUS) YANG DIKONVERSIKAN

\begin{tabular}{|c|c|c|c|c|c|c|c|c|c|c|c|c|}
\hline \multirow{2}{*}{$\begin{array}{l}\text { Respon- } \\
\text { den }\end{array}$} & \multicolumn{10}{|c|}{ Pertanyaan } & \multirow{2}{*}{ Jumlah } & \multirow{2}{*}{$\begin{array}{l}\text { Hasil } \\
\text { Kali } \\
2.5\end{array}$} \\
\hline & 1 & 2 & 3 & 4 & 5 & 6 & 7 & 8 & 9 & 10 & & \\
\hline 1 & 2 & 3 & 3 & 2 & 2 & 3 & 3 & 4 & 2 & 2 & 26 & 65 \\
\hline 2 & 3 & 4 & 2 & 4 & 3 & 4 & 3 & 2 & 2 & 2 & 29 & 72,5 \\
\hline 3 & 2 & 5 & 3 & 4 & 3 & 5 & 3 & 4 & 3 & 4 & 36 & 90 \\
\hline 4 & 2 & 3 & 3 & 4 & 2 & 4 & 3 & 5 & 1 & 4 & 31 & 77,5 \\
\hline 5 & 2 & 3 & 2 & 4 & 3 & 5 & 2 & 3 & 2 & 4 & 30 & 75 \\
\hline 6 & 0 & 5 & 3 & 2 & 3 & 5 & 3 & 1 & 2 & 4 & 28 & 70 \\
\hline 7 & 2 & 5 & 2 & 2 & 3 & 4 & 2 & 5 & 2 & 5 & 32 & 80 \\
\hline 8 & 1 & 4 & 3 & 2 & 2 & 4 & 2 & 5 & 3 & 4 & 30 & 75 \\
\hline 9 & 2 & 2 & 3 & 4 & 3 & 5 & 1 & 4 & 2 & 4 & 30 & 75 \\
\hline 10 & 1 & 2 & 3 & 3 & 3 & 4 & 3 & 5 & 2 & 4 & 30 & 75 \\
\hline 11 & 0 & 3 & 2 & 3 & 2 & 4 & 2 & 3 & 0 & 1 & 20 & 50 \\
\hline 12 & 2 & 4 & 3 & 4 & 2 & 4 & 2 & 2 & 2 & 2 & 27 & 67,5 \\
\hline 13 & 0 & 4 & 3 & 4 & 2 & 3 & 3 & 2 & 1 & 4 & 26 & 65 \\
\hline 14 & 2 & 3 & 1 & 2 & 2 & 4 & 2 & 5 & 1 & 4 & 26 & 65 \\
\hline 15 & 2 & 4 & 2 & 4 & 1 & 4 & 2 & 4 & 2 & 4 & 29 & 72,5 \\
\hline 16 & 2 & 5 & 3 & 4 & 2 & 5 & 3 & 4 & 3 & 5 & 36 & 90 \\
\hline 17 & 2 & 5 & 2 & 2 & 3 & 4 & 2 & 4 & 3 & 5 & 32 & 80 \\
\hline 18 & 2 & 4 & 2 & 5 & 3 & 5 & 2 & 4 & 2 & 4 & 33 & 82,5 \\
\hline 19 & 3 & 4 & 2 & 4 & 2 & 4 & 3 & 2 & 2 & 5 & 33 & 82,5 \\
\hline 20 & 0 & 4 & 3 & 4 & 2 & 3 & 3 & 1 & 0 & 1 & 21 & 52,5 \\
\hline & & & & & & & & & & otal & & 73,13 \\
\hline
\end{tabular}

Dari hasil konversi data pengujian sistem usabilty scale (SUS), diperoleh skor rata-rata interpretasi System Usabilty Scale sebesar 73.13. Dalam pengelompokan SUS skor percentile rank, nilai 73.13 berada pada grade $C$ dimana dalam penilaian tersebut aplikasi ini dapat diterima dan digunakan dengan mudah oleh pengguna.

\section{E. Pengujian Sudut untuk Menampilkan Objek 3 Dimensi}

Pengujian aplikasi markerless augmented reality ini menggunakan 3 jenis tipe smartphone yang berbeda resolusi kamera dan spesifikasinya. Pengujian ini bertujuan untuk mengetahui tingkat toleransi kamera terhadap sudut penempatan kamera smartphone saat menampilkan objek 3 dimensi. Alat yang digunakan untuk mengukur sudut pada penelitian ini menggunakan penggaris busur. Perangkat yang digunakan dapat dilihat pada Tabel IV.

TABEL IV. SPESIFIKASI PERANGKAT

\begin{tabular}{|l|l|l|l|}
\hline Nama & Perangkat 1 & Perangkat 2 & Perangkat 3 \\
\hline Merek & $\begin{array}{l}\text { Xiaomi Redmi } \\
5+\end{array}$ & Oppo A83 & $\begin{array}{l}\text { Samsung Galaxy } \\
\text { S4 }\end{array}$ \\
\hline OS & 7.1 .2 (Nougat) & 7.1 .1 (Nougat) & 4.4 (KitKat) \\
\hline $\begin{array}{l}\text { Ukuran } \\
\text { Layar }\end{array}$ & $5.99^{\prime \prime}$ & $5.7 ”$ & $5 "$ \\
\hline $\begin{array}{l}\text { Resolusi } \\
\text { Kamera }\end{array}$ & $12 \mathrm{MP}$ & $13 \mathrm{MP}$ & $13 \mathrm{MP}$ \\
\hline CPU & $\begin{array}{l}\text { Octa-core 2 } \\
\text { GHz }\end{array}$ & $\begin{array}{l}\text { Octa-core 2.5 } \\
\text { GHz }\end{array}$ & $\begin{array}{l}\text { Eynos 8 core } \\
\text { (octa-core) }\end{array}$ \\
\hline
\end{tabular}




\begin{tabular}{|l|l|l|l|}
\hline RAM & 4 GB & 3 GB & 2 GB \\
\hline
\end{tabular}

Pengujian dilakukan dengan cara mengarahkan 3 perangkat smartphone dan meletakkan posisi kamera perangkat smartphone Android pada sudut $20^{\circ}$, sudut $30^{\circ}$, sudut $60^{\circ}$, sudut $90^{\circ}$, sudut $95^{\circ}$, dan sudut $100^{\circ}$. Hasil ini dapat dilihat pada Tabel V.

TABEL V. HAsil PEngujian Sudut

\begin{tabular}{|c|c|c|}
\hline Perangkat & Sudut & Hasil \\
\hline \multirow{6}{*}{ Xiaomi Redmi 5+ } & $20^{\circ}$ & Objek 3D Tampil \\
\hline & $30^{\circ}$ & Objek 3D Tampil \\
\hline & $60^{\circ}$ & Objek 3D Tampil \\
\hline & $90^{\circ}$ & Objek 3D Tampil \\
\hline & $95^{\circ}$ & Objek 3D Tidak Tampil \\
\hline & $100^{\circ}$ & Objek 3D Tidak Tampil \\
\hline \multirow{6}{*}{ Oppo A83 } & $20^{\circ}$ & Objek 3D Tampil \\
\hline & $30^{\circ}$ & Objek 3D Tampil \\
\hline & $60^{\circ}$ & Objek 3D Tampil \\
\hline & $90^{\circ}$ & Objek 3D Tampil \\
\hline & $95^{\circ}$ & Objek 3D Tidak Tampil \\
\hline & $100^{\circ}$ & Objek 3D Tidak Tampil \\
\hline \multirow{6}{*}{ Samsung Galaxy S4 } & $20^{\circ}$ & Objek 3D Tampil \\
\hline & $30^{\circ}$ & Objek 3D Tampil \\
\hline & $60^{\circ}$ & Objek 3D Tampil \\
\hline & $90^{\circ}$ & Objek 3D Tampil \\
\hline & $95^{\circ}$ & Objek 3D Tidak Tampil \\
\hline & $100^{\circ}$ & Objek 3D Tidak Tampil \\
\hline
\end{tabular}

Berdasarkan hasil pengujian sudut pada tiga perangkat smartphone Android yaitu Xiaomi Redmi 5+, Oppo A83 dan Samsung Galaxy S4, aplikasi dapat menampilkan objek 3 dimensi dengan sudut pendeteksian $20^{\circ}, 30^{\circ}, 60^{\circ}$ dan $90^{\circ}$. Namun apabila sudut pendeteksian melebihi dari sudut $90^{\circ}$ seperti pada sudut $95^{\circ}$ dan $100^{\circ}$ objek tidak tampil, hal ini dikarenakan marker semu yang digunakan telah berubah dari posisi awalnya.

\section{F. Pengujian Jarak Maksimal Objek 3 Dimensi}

Pengujian ini untuk menentukan deteksi jarak sehingga dapat menetapkan batas maksimal objek 3 dimensi dapat dimunculkan. Pengujian ini dilakukan dengan cara mengarahkan smartphone ke suatu ruangan dengan berbagai ukuran dan menempatkan objek 3 dimensi ke daerah terjauh dari ruangan tersebut. Pengujian jarak dilakukan pada 3 perangkat smartphone berbeda dan hasilnya dapat dilihat pada Tabel VI.

TABEL VI. HASIL PENGUJIAN JARAK MAKSIMAL

\begin{tabular}{|l|l|}
\hline Perangkat & Jarak Maksimal \\
\hline Xiaomi Redmi 5+ & 7 meter \\
\hline Oppo A83 & 6,5 meter \\
\hline Samsung Galaxy S4 & 6,5 meter \\
\hline
\end{tabular}

Pada Tabel VI. menjelaskan bahwa perangkat Xiaomi Redmi 5+ dapat memunculkan objek 3 dimensi dengan jarak maksimal 7 meter, selanjutnya Oppo A83 dan Samsung Galaxy S4 dapat memunculkan objek 3 dimensi dengan jarak maksimal 6,5 meter. Perbedaan dari jarak maksimal dikarenakan spesifikasi dari alat penguji itu sendiri dan kemampuan dari kamera smartphone itu sendiri.

\section{KESIMPULAN}

Aplikasi Simulasi dekorasi ruangan dengan memanfaatkan teknologi Markerless Augmented Reality telah berhasil dirancang dengan menggunakan aplikasi Android Studio dan dengan bantuan library Wikitude serta telah berhasil diimplementasikan pada smartphone Android. Berdasarkan hasil pengujian Black Box keseluruhan fungsional tombol yang ada pada aplikasi dinyatakan telah berhasil dijalankan sesuai fungsinya. Sedangkan berdasarkan hasil usability test menggunakan metode System Usabilty Scale, nilai rata-rata akhir yang diperoleh sebesar 73,13 yang berarti berada pada grade $C$, dapat diterima (acceptable) dan digunakan dengan mudah oleh pengguna. Selain itu, berdasarkan pengujian pada pendeteksian sudut aplikasi markerless augmented reality, diperoleh hasil bahwa untuk ketiga alat penguji yaitu perangkat Android Xiaomi Redmi 5+, Oppo A83, dan Samsung Galaxy S4 dapat menampilkan objek 3 dimensi antara sudut $20^{\circ}$ sampai dengan sudut $90^{\circ}$, namun apabila sudut pendeteksian melebihi dari sudut $90^{\circ}$ seperti pada sudut $95^{\circ}$ dan $100^{\circ}$ objek tidak tampil, hal ini dikarenakan marker semu yang digunakan telah berubah dari posisi awalnya. Berdasarkan pengujian jarak yang dilakukan diperoleh hasil jarak maksimal objek dapat ditampilkan dengan menggunakan perangkat Xiaomi Redmi 5+ adalah 7 meter, sedangkan dengan perangkat Oppo A83 dan Samsung Galaxy S4 adalah 6,5 meter.

Aplikasi ini dapat dikembangkan dengan memperbanyak dan meningkatkan kualitas objek 3 dimensi model furniture. Objek 3 dimensi yang akan ditampilkan diharapkan memiliki ukuran yang sama dengan objek aslinya. Selain itu, dapat ditambahkan fitur untuk merubah warna objek 3D sesuai kebutuhan ruangan dan merubah hasil perancangan dekorasi yang telah dilakukan sebelumnya. Aplikasi saat ini baru dapat melakukan capture pada hasil dekorasi ruangan. Pengujian terhadap pelacakan objek perlu juga memperhatikan aspek pencahayaan, sehingga dapat diketahui pada tingkat cahaya seperti apa objek 3 dimensi dapat ditampilkan.

\section{DAFTAR PUSTAKA}

[1] R. T. Azuma, "A Survey of Augmented Reality," Presence Teleoperators Virtual Environ., vol. 6, no. 4, pp. 355-385, Aug. 1997.

[2] J. Herling and W. Broll, "Markerless Tracking for Augmented Reality," in Handbook of Augmented Reality, New York, NY: Springer New York, 2011, pp. 255-272.

[3] A. Setiawan, T. D. Tambunan, and R. Hendriyanto, 
“Android Augmented Reality Untuk Menampilkan Katalog Furniture Secara Tiga Dimensi (3d) Berdasarkan Objek Marker," e-Proceeding Appl. Sci., vol. 2, no. 1, pp. 38-50, 2016.

[4] U. E. N. Rochmah and A. Rakhmadi, "Penggunaan Augmented Reality untuk Mensimulasikan Dekorasi Ruangan Secara Real Time," Techno.COM, vol. 15, no. 4, pp. 312-319, 2016.

[5] P. Renukdas, R. Ghundiyal, H. Gadgil, and V. Pathare, "Markerless Augmented Reality Android App For Interior Decoration," Int. J. Eng. Res. Technol., vol. 2, no. 4, pp. 1367-1373, 2013.

[6] W. Viyanon, T. Songsuittipong, P. Piyapaisarn, and S. Sudchid, "AR Furniture: Integrating Augmented Reality Technology to Enhance Interior Design using Marker and Markerless tracking," in Proceedings of the 2nd International Conference on Intelligent Information Processing - IIP'17, 2017, pp. 1-7.

[7] M. Jumarlis and M. Mirfan, "Implementation of
Markerless Augmented Reality Technology Based on Android to Introduction Lontara in Marine Society," IOP Conf. Ser. Earth Environ. Sci., vol. 156, p. 012017, May 2018.

[8] L. Madden, Professional Augmented Reality Browsers for Smartphones: Programming for Junaio, Layar and Wikitude (1st ed.). Wiley Publishing, 2011.

[9] N. Safaat H, Pemrograman Aplikasi Mobile Smartphone dan Tablet PC Berbasis Android. Bandung: Informatika, 2011.

[10] S. Nidhra, "Black Box and White Box Testing Techniques - A Literature Review," Int. J. Embed. Syst. Appl., vol. 2, no. 2, pp. 29-50, Jun. 2012.

[11] J. Brooke, "SUS-A quick and dirty usability scale," in Usability Evaluation In Industry, 1996, pp. 189-194.

[12] A. Bangor, P. Kortum, and J. Miller, "Determining What Individual SUS Scores Mean: Adding an Adjective Rating Scale," J. Usability Stud., vol. 4, no. 3, pp. 114-123, 2009. 